\title{
Sivas Cumhuriyet Üniversitesi Yerleşkesinde Güneş Enerjisi Santralinin Ekonomik Analizi
}

\section{Economic Analysis of Solar Power Plant in Sivas Cumhuriyet University Campus}

\author{
Vekil Sarı $1^{*} \mathbb{D}$, Fatih Yavuz Özyiğit 1
}

${ }^{1}$ Sivas Cumhuriyet Üniversitesi, Mühendislik Fakültesi, Elektrik Elektronik Mühendisliği Bölümü, Sivas, TÜRKIYY Sorumlu Yazar / Corresponding Author*: vsari@cumhuriyet.edu.tr

\author{
Geliş Tarihi / Received: 22.09.2019 \\ Araștırma Makalesi/Research Article \\ Kabul Tarihi / Accepted: 07.01.2020 \\ DOI: $10.21205 /$ deufmd.2020226519 \\ Atıf șekli/How to cite: SARI, V., ÖZYiĞIT, F.Y.(2020). Sivas Cumhuriyet Üniversitesi Yerleşkesinde Güneş Enerjisi Santralinin Ekonomik Analizi.
} DEUFMD 22(65), 517-526.

Öz

Bu çalışmada Sivas Cumhuriyet Üniversitesi yerleşkesinde yapılabilecek güneş enerji santralinin ekonomik analizi yapılmıştır. Santral için gerekli hesaplamalar PVsyst programı yardımıyla elde edilmiștir. Bu çalıșmanın sonucunda monokristal modüllerle kurulan sistemin veriminin polikristal modüllerle kurulan sistemin veriminden daha yüksek olduğu, fakat monokristal modüllerle kurulan sistemin daha maliyetli olduğu görülmüștür. Yapılan çalıșmada 30 yıl boyunca gerçekleşecek enerji satışından elde edilen getiri monokristal paneller için 4.140.900\$, polikristal paneller için 4.111.100\$ olarak hesaplanmıştır. Sistem ömrü boyunca elde edilen getiri arasındaki fark 29.800\$' dır. Kurulumu düşünülen sistemin monokristal modüllerden oluşması hem modül veriminin daha yüksek olması hem de sistem ömrü sonunda getirdiği kazancın daha fazla olması sebebiyle daha mantıklı olmaktadır. Bu çalışmada elde edilen bulguların, Sivas Cumhuriyet Üniversitesi yerleşkesinde ileride yapılması muhtemel olan güneș enerjisi santralinin kurulumunda faydalı olacağı düşünülmektedir.

Anahtar Kelimeler: Yenilenebilir Enerji, Güneș Enerjisi, PVsyst, Ekonomik Analiz

\begin{abstract}
In this study, the economic analysis of the solar power plant can be built in the Sivas Cumhuriyet University campus was conducted. The calculations for the power plant to be installed were obtained by means of the PVsyst program. As a result of this study, the efficiency of the system established by monocrystalline modules was found to be higher than the efficiency of the system established with polycrystalline modules. However, the system installed with monocrystalline modules was found to be costlier. In the study, the yield obtained from the sales of energy for 30 years was calculated as $\$$ $4,140,900$ for monocrystalline panels and $\$ 4,111,100$ for polycrystalline panels. The difference between the yield obtained during the life of the system is $\$ 29,800$. It is concluded that the system, which is planned to be installed, consists of monocrystalline modules will be a more logical because of the higher module yield and the higher the gain of the system life. It is thought that the results obtained in this study will be useful in the installation of solar power plant to be constructed in Sivas Cumhuriyet University campus.
\end{abstract}

Keywords: Renewable Energy, Solar Energy, PVsyst, Economic Analysis 


\section{Giriş}

İnsan nüfusunun hızla artması ve enerji ihtiyacının doğru bir şekilde planlanamaması birçok soruna sebep olmaktadır. İşsizlik, yoksulluk, çevre kirliliği ve enerji talebi bunlardan bazılarıdır. 1999 yılında 6 milyar olan insan nüfusu 2011 yılında 1 milyar artarak 7 milyara ulaşmıştır. 2050 yılında 9,7 milyar ve 2100 yılında ise 11,2 milyar olacağı tahmin edilmektedir [1].

İnsanlık, günümüze kadar enerji ihtiyacını büyük oranda fosil kaynaklardan sağlamış ve fosil kaynakların çevreye verdiği tahribatı göz önüne almamıștır. Çevreye etkileri düşünülmeden kullanılan fosil kaynaklar sera gazı emisyonlarına sebebiyet vermekte, bütün canlı hayatını tehdit etmekte ve günümüzün en büyük sorunlarından biri olan iklim değișikliğine neden olmaktadır. Fosil kaynaklar savaşların da ana unsurlarındandır. Politika yapıcıların artık önem verdiği bir konu haline gelen yenilenebilir enerji, ülkemizi de enerjide dışa bağımlılıktan kurtaracak çözümlerden birisidir. Fosil kaynakların ömrü sınırlıdır. Enerji ve Tabii Kaynaklar Bakanlığı' nın 01 Ocak 2017 tarihinde yayınladığı Dünya ve Türkiye Enerji ve Tabii Kaynaklar Görünümü belgesine göre; dünyadaki toplam petrol rezervleri 1,7 trilyon varil civarında olup bu miktar, yaklaşık 51 yıllık tüketimi karşılamaktadır. Dünya doğalgaz rezervi 2015 yılı sonunda 187 trilyon $\mathrm{m}^{3}$ olarak belirlenmiş olup bu miktar küresel üretimi 53 yıl gibi bir süre boyunca karșlayabilmektedir. Dünya kömür rezervleri ise küresel üretimi 114 yıl boyunca karşllayabilmektedir [2]. Bu durum yenilenebilir enerji kaynaklarına geçişi zorunlu kılmaktadır.

Ülkemizde 2017 verilerinden hareketle petrolde ithalata bağımlılığımız \%94,6, doğalgazda ise \%99,4 olarak gerçekleșmiștir [3]. 2018 yılında elektrik üretimimizin \%37,3'ü kömürden, $\% 29,8$ 'i doğalgazdan, \%19,8'i hidrolik enerjiden, $\% 6,6$ 'sı rüzgârdan, $\% 2,6$ 'sı güneșten, $\% 2,5$ 'i jeotermal enerjiden, ve $\% 1,4$ 'ü diğer kaynaklardan elde edilmiștir [4]. Bulunduğumuz coğrafya yenilenebilir enerji kaynakları açısından oldukça verimli olmasına rağmen, bu kaynaklar yeterince kullanılmamaktadır. Elektrik enerjisi üretiminde yenilenebilir enerji kaynaklarının kullanımı ile fosil kaynakların kullanımı azalacaktır. Böylelikle enerjide dışa bağımlılığımızda azalacaktır.

Enerji ve Tabii Kaynaklar Bakanlığının hazırladığı Türkiye Güneș Enerjisi Potansiyeli Atlasına (GEPA) göre, yıllık toplam güneşlenme süresi 2.741 saat (günlük ortalama 7,5 saat), yıllık toplam gelen güneş enerjisi 1.527 $\mathrm{kWh} / \mathrm{m} 2 . y \mathrm{ll} \quad$ (günlük ortalama 4,18 $\mathrm{kWh} / \mathrm{m} 2$.gün) olmaktadır [5].

Türkiye' nin ay bazında sahip olduğu küresel radyasyon değerleri ve güneșlenme süreleri Şekil 1 ve Şekil 2' deki grafiklerde gösterilmektedir.

Şekil 3' de ise Türkiye fotovoltaik güç potansiyel haritası gösterilmektedir. Haritadan da görüldügü gibi ülkemiz güneş enerji potansiyeli bakımından oldukça verimli bir konumdadır.

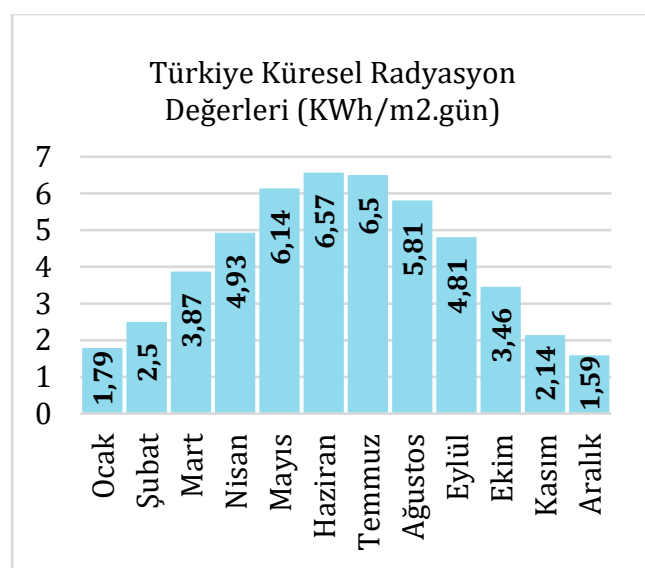

Șekil 1. Türkiye küresel radyasyon değerleri [6].

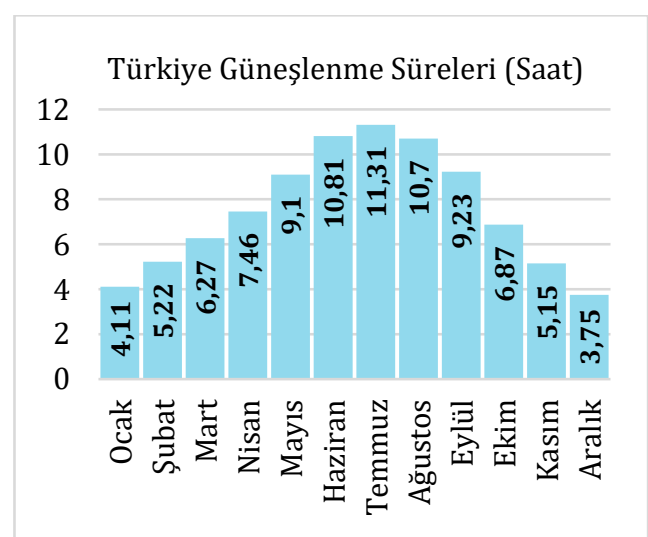

Şekil 2. Türkiye güneşlenme süreleri [6]. 


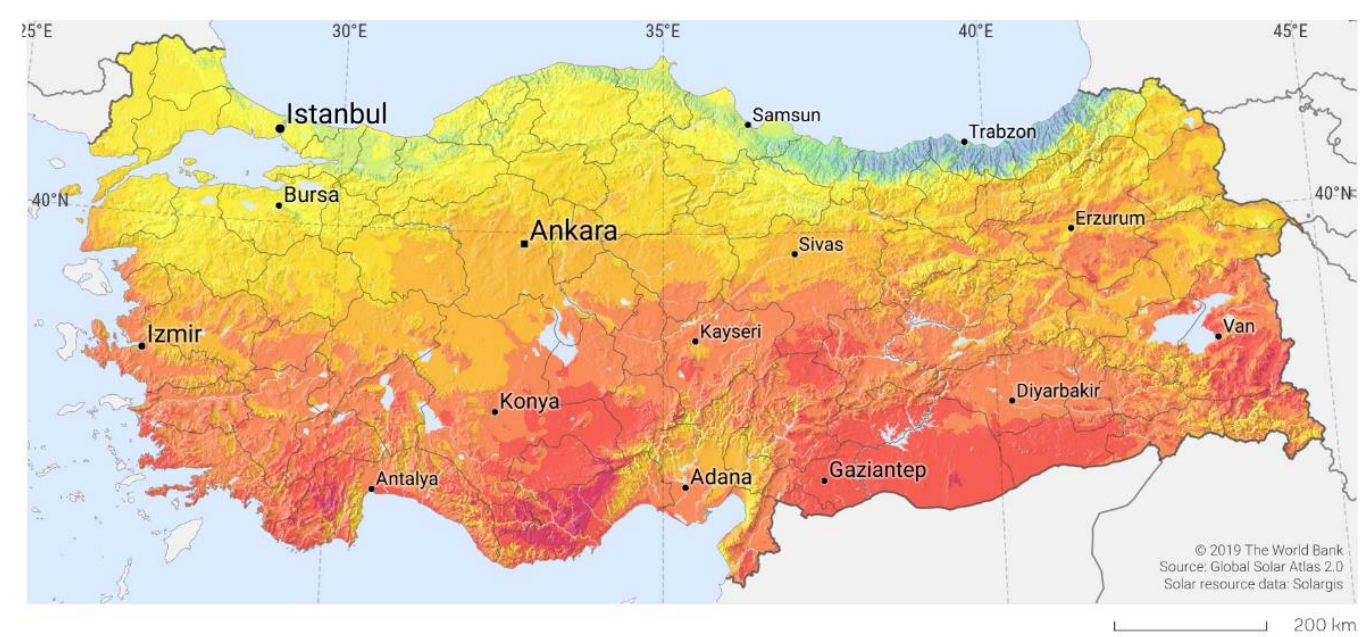

PV çıkışııın uzun vadeli ortalaması, 1994'ten (doğuda 1999) 2018 yılına kadar geçen süre

\begin{tabular}{|c|c|c|c|c|c|c|}
\hline Günlük toplam & 3.0 & 3.4 & 3.8 & 4.2 & 4.6 & \multirow[t]{2}{*}{5.0} \\
\hline Yillık toplam & 1095 & 1241 & 138 & 1534 & 1680 & \\
\hline
\end{tabular}

Şekil 3. Türkiye fotovoltaik güç potansiyel haritası [7].

Ülkemizin sahip olduğu güneș enerjisi potansiyelinin yüksek olması sebebiyle daha önce bu alanda birçok çalışmalar yapılmıştır.

Bu alanda yapılan bir çalıșmada [8], Uşak ilinde bulunan derbent köyünde 24.100 m2' lik bir araziye güneș enerjisi santrali için fizibilite çalışması gerçekleştirilmiştir. Kurulu gücü 1.950 kWe olarak $25^{\circ}$ sabit açılı tașıyıcı sistemin ıșınım ve elektrik üretim değerleri PVGIS verileri yardımıyla hesaplanmıștır. Yıllık $3.150 .000 \mathrm{kWh}$ elektrik üretileceğini, sistemin ömrünün 25 yll olacağını ve sistemin 15 yıl kâr edeceği öngörülmüștür.

Yapılan bașka bir çalışmada [9], Erzincan ili için tasarlanan $50 \mathrm{~kW}$ kurulu gücünde güneş enerjisi santralinin ekonomik analizi incelenmiștir. Sistem analizi için PVsyst programı kullanılmıştır. Tasarım sabit eğik sistem olarak gerçekleștirilmiştir. PVsyst programı ile ışınım miktarının $1.481 \mathrm{kWh} / \mathrm{m} 2$ olacağı ve elde edilecek gücün 44,5 kW olacağı tespit edilmiştir. Şebekeye yıllık $70.459 \mathrm{kWh}$ enerji verileceği öngörülmüştür. Yatırım maliyetinin $76.641 \$$ ve sistemin yıllık net gelirinin $8.915,5 \$$ olacağ hesaplanmıștır.

$\mathrm{Bu}$ alanda yapılan diğer bir çalışmada [10], Diyarbakır bölgesinde yenilenebilir enerji kullanımının artması ve elektrik giderlerinin önemli bir oranda azaltılması amaçlanmış ve bulundukları kuruma $250 \mathrm{kWp}$ gücüne sahip güneş enerjisi santrali kurulumu gerçekleștirilmiştir. Kurum içerisinde 3.500 m2 alana 245-255 W arasında değişen polikristal panellerle bir güneş tarlası oluşturulması planlanmıştır. Elde edilen enerjinin kurum trafosu üzerinden aktarımı gerçekleştirilecektir. Planlanan sistem 6 ylda kendini amorti etmektedir.

Başka bir çalışmada [11], Artvin Çoruh Üniversitesi Seyitler Yerleşkesinin elektrik ihtiyacını karşılamak üzere güneş paneli ve rüzgâr türbinlerinden oluşan hibrit bir sistemin optimizasyonu gerçekleştirilmiştir. $\mathrm{Bu}$ çalışmada RETScreen programı yardımıyla optimum koşullarda ne kadar fayda sağlanacağ belirlenmiștir. Ayrıca hibrit sistem kullanımının artıları irdelenmiș ve yatırımcıya mali tablo ve fiziki koșullarla ilgili ön bilgi sunulmuştur.

Diğer bir çalıșmada [12], yıllık küresel radyasyon miktarı farklı olan 5 farklı bölgede enerji birim maliyet hesapları gerçekleștirilmiştir. Bu 5 bölgede 10 MW' lık kurulu güce sahip güneș enerjisi santralinin yatırım maliyetleri ve elde edilen elektrik enerjisi miktarları hesaplanmıștır. $\mathrm{Bu}$ hesaplamalar PVsyst programı ile gerçekleştirilmiştir. Sonuç olarak Türkiye' de 
günün koșullarında yeterli olmayan teșvikler nedeniyle yatırımcıya zarar ettireceğini fakat Almanya ve İspanya' da ise uzun vadede kâr edecekleri ortaya çıkmıștır. Ayrıca monokristal panel kullanımının polikristal panellere göre daha fazla enerji üreteceği ama sistem maliyetini de artırdığı sonucuna varılmıștır.

$\mathrm{Bu}$ çalışmalardan başka güneş enerjisi sistemlerinin panel açıları ile ilgili çalıșmalarda yapılmıştır. Panel açısı ile ilgili yapılan bir çalıșmada [13], güneș panellerinin açısının verime etkisi araştırılmış ve mevcut konuma göre en uygun açı belirlenmiștir. Başka bir çalıșmada [14], İstanbul, Ankara, Erzurum ve Adana illeri için yılın her ayında kullanılabilecek optimum eğim açları, teorik hesaplama ve Hottel \& Woertz metotları ile ayrı ayrı belirlenmiş ve birbirleriyle karşılaştırılmıștır.

Sivas iline ait toplam küresel radyasyon değeri yaklașık olarak Türkiye ortalamasındadır ve güneșlenme süresi de oldukça iyidir. $\mathrm{Bu}$ çalışmada bu durum göz önünde bulundurularak üniversite yerleșkesine kurulması muhtemel bir güneş enerji santralinin ekonomik fizibilitesi incelenmiştir.

\section{Materyal ve Metot}

Güneș enerjisi üretim sistemlerinin simülasyonunu, hesaplamalarını ve analizini yapan PV*SOL, Helioscope, Polysun, PVsyst gibi birçok program ve PVGIS gibi online veritabanı platformu vardır [15]. Bu çalışmada, kurulumu muhtemel bir güneş enerjisi santralinin iklimsel ve ekonomik analizi için PVsyst programı kullanılmıștır. PVsyst programı fotovoltaik sistemlerin ayrıntılı çalıșmasını, boyutlandırmasını ve saatlik simülasyonlarını yapabilmektedir. PVsyst programında ayrıca:

- Ayrıntılı güneș ıșınım değerleri

- Bölge kirlilik oranları ve yer yansıma oranları

- Yerleşim planları

- Meteorolojik veriler

- Güneș panelleri ve evirici özellikleri

- Güneş panellerinin yıllık güç düşümü oranları

- Sebeke özellikleri

- Kablo mesafeleri

gibi detaylar bulunmaktadır. PVsyst programı benzer programlara göre gerçek değerlere oldukça yakın sonuçlar verebilmektedir. Ayrıca programın hesaplama sonuçlarına finans kuruluşları kredi sağlamaktadır [16]. PVsyst güneş enerjisi simülasyon programı ile aynı zamanda 3 boyutlu modellemeler yapılarak gölgelenme durumları analiz edilebilmektedir [17]. Küresel güneş ışınım şiddeti, güneşlenme süresi ve hava sıcaklığı verilerinin analizi için başka yöntemlerde kullanılabilir [18].

\section{1. İklimsel veriler}

Șekil 4, Șekil 5 ve Șekil 6' da Sivas ilinin Meteonorm programı ile elde edilmiş iklimsel verileri gösterilmektedir. Şekil 4, Şekil 5 ve Şekil 6 ' da yatay eksende ay isimlerinin baș harfleri verilmiștir.

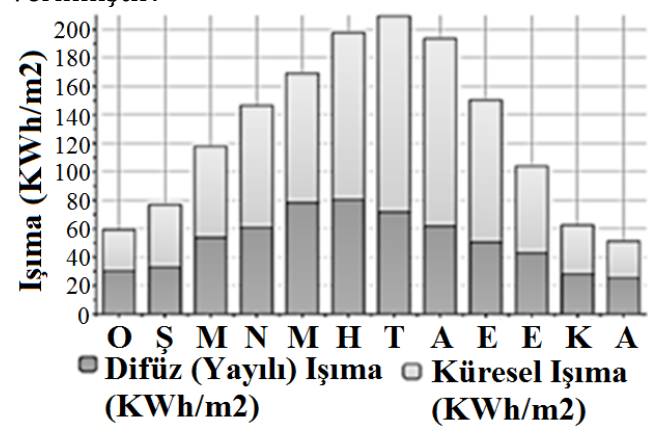

Șekil 4. Sivas ilinin aylık ıșınım grafiği.

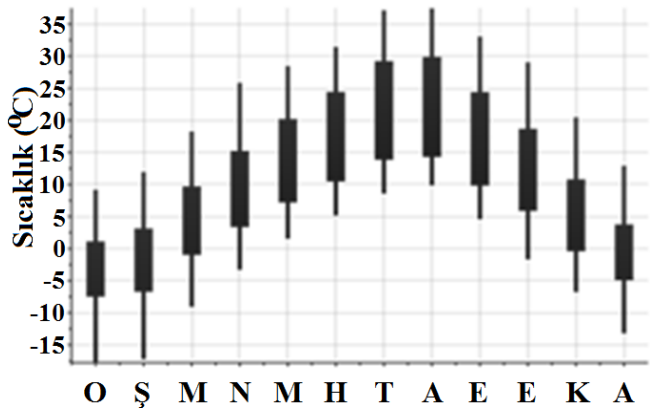

Şekil 5. Sivas ilinin aylık sıcaklık grafiği.

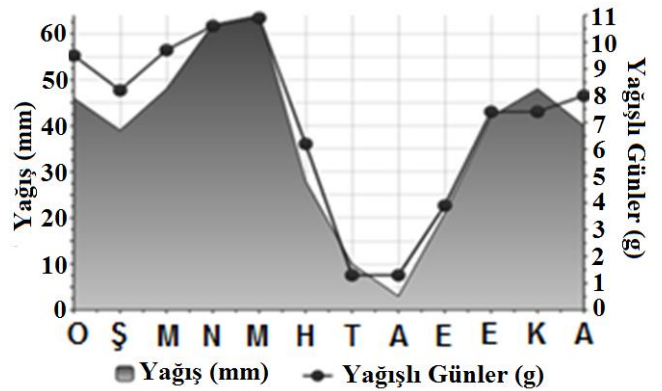

Şekil 6. Sivas ilinin aylık yağış grafiği.

\subsection{Yer seçimi}

Güneş enerjisi santralinin kurulması için üniversite yerleşkesinde, yakın gölgeleme unsurlarının bulunmadığı, arazi eğiminin \%2 
olduğu, sulama alanı dıșında, engebeli olmayan, ulaşımın kolay olduğu ve enerji nakil hattına yakın $18.000 \mathrm{~m} 2$ ' lik bir arazi seçimi yapılmıştır. Şekil 7' de güneș santralinin kurulacağı arazi görülmektedir.

Hava sirkülasyonunun panel verimi üzerine doğrudan etkisi vardır. Panellerin yerleștirileceği arazinin çevresinde rüzgarı kısıtlayan bir engel bulunmamaktadır. Böylelikle rüzgar, panellerin sıcaklığınının azalmasına yardımcı olarak sistemin verimini artırmaktadır.

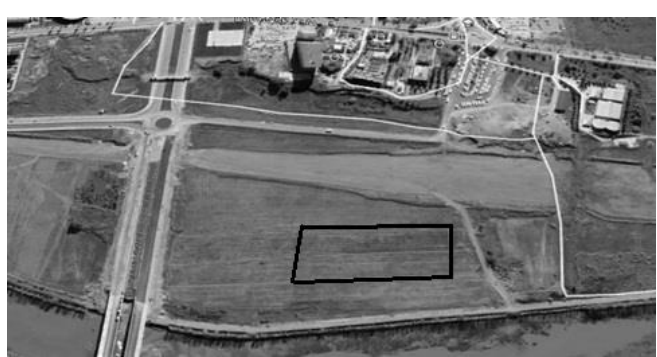

Şekil 7. Güneş santralinin kurulacağı arazi.

\subsection{Tasarım}

Santralin lisanssız olarak kurulumu düşünüldügüunden ve mali nedenlerden dolayı santralin gücü $1 \mathrm{MW}$ düşünülmüștür.

Sistem tasarımı için; yaygın olarak kullanılan ve tedarik kolaylığı bakımından Canadian Solar ve Yingli Solar firmalarının panelleri tercih edilmiştir [19]. İnvertör tercihinde ise şebeke beslemeli güneş enerji sistemlerinde dünyanın en büyük üreticilerinden olan, yaygın kullanımı ve tedarik kolaylığı bakımından Kaco New Energy markasının invertörü tercih edilmiştir [20].

Santralin kurulacağı araziye gölgeleme etkisi gözönünde bulundurularak 3224 adet panel yerleştirilmiștir. Paneller arası mesafe 5,8 metredir. 806 adet sehpa ve her sehpada 4 adet panel vardır. 15 adet inverter kullanılmıştır. Şekil 8' de panellerin yerleșimi görülmektedir.

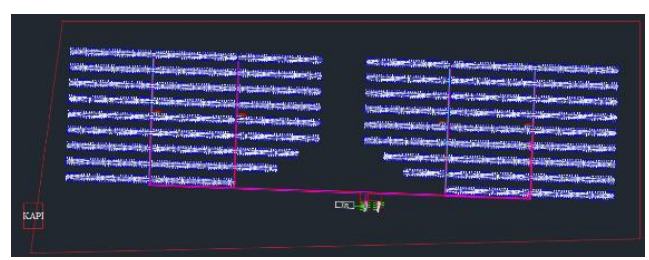

Şekil 8. Panellerin yerleşimi [21].
Kablo olarak aşağıda özellikleri verilen kablolar seçilmiştir.

- 4 mm2 solar kablo 12.000 metre

- $6 \mathrm{~mm} 2$ solar kablo 10.000 metre

- 4X16 mm2 YXV-R (N2XY) kablo (miktar 10001 set)

- 4X70 mm2 YXV-R (N2XY) kablo (miktar 10001 set)

- 4X95 mm2 YXV-R (N2XY) kablo (miktar 10001 set)

- 1x120 mm2 NYY (miktar 1000-1 set)

- XLPE 1x240/35 kablo (miktar 1000-1 set)

Kurulum yapılacak arazinin küresel radyasyon miktarı yıllık $1.573 \mathrm{kWh} / \mathrm{m} 2$ ' dir. Panel eğim açısı $35^{\circ}$ ve azimuth açısı $0^{\circ}$ olarak sabit eksenli tasarım ile optimum verim sağlanmaktadır.

Tablo 1. Kullanılacak FV panel özellikleri.

\begin{tabular}{lll}
\hline Üretici & $\begin{array}{l}\text { Canadian Solar } \\
\text { Inc. }\end{array}$ & Yingli Solar \\
\hline Ürün & $\begin{array}{l}\text { Monokristal FV } \\
\text { modül }\end{array}$ & $\begin{array}{l}\text { Polikristal FV } \\
\text { modül }\end{array}$ \\
\hline Model & CS6X-310M & YL310P-35b \\
\hline Verim & $\% 16.14$ & $\% 15.98$ \\
\hline Çıkıș Gücü & $310 \mathrm{~W}$ & $310 \mathrm{~W}$ \\
\hline Hücre Sayısı & 72 hücreli & 72 hücreli \\
\hline Çalışma sıcaklığı & $-40^{\circ} \mathrm{C} \sim,+85$ & $-40^{\circ} \mathrm{C} \sim,+85$ \\
\hline Ürün Garantisi & 10 yıl & 10 yıl \\
\hline
\end{tabular}

Tablo 2. Kullanılacak invertör özellikleri.

\begin{tabular}{ll}
\hline Üretici & Kaco New Energy \\
\hline Ürün & Powador 72.0 TL3 Park XL \\
\hline Verim & $\% 98.0$ \\
\hline Mpp Aralığı & $200 \mathrm{~V}-850 \mathrm{~V}$ \\
\hline Mpp Takipçi Sayısı & 3 \\
\hline Max.Güç/Takipçi & $24 \mathrm{~kW}$ \\
\hline Ürün Garanti & 10 yıl \\
\hline
\end{tabular}

Tablo 1 ve Tablo 2' de panellerin ve invertörün özellikleri gösterilmiştir. Tasarım şebekeye bağlı sistem olarak düşünülmüștür. Şekil 9' da şebekeye bağlı sistemin genel yapısı görülmektedir. 


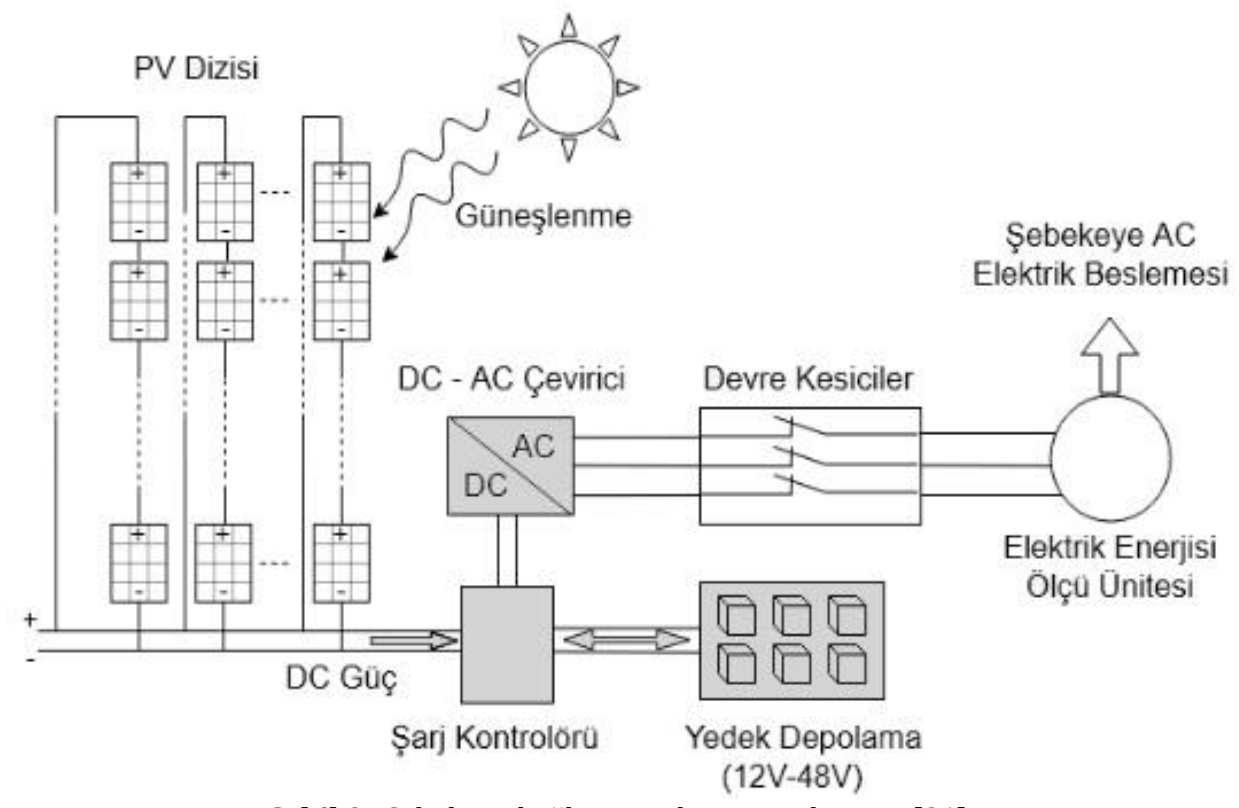

Şekil 9. Şebekeye bağlı sistemlerin genel yapısı [21].

\subsection{Finansal analiz}

18.11.2019 tarihli Türkiye Cumhuriyeti Merkez Bankası kur verileri baz alınarak pazar araştırması yapılmış ve maliyet tablosu oluşturulmuştur. Tablo 3' de kur değerleri ve Tablo 4' de maliyet tablosu verilmiștir. Ekonomik analiz için Tablo 5' deki kabuller yapılmıstır. Burada 10 yıllık alım garantisi sonunda elektrik birim fiyatında \% 40' lık bir düşüş öngörülmüştür.

Tablo 3. Kur değerleri.

\begin{tabular}{ll}
\hline ABD dolarl/TL & Euro/TL \\
\hline 5.7407 & 6.3492 \\
\hline
\end{tabular}

Tablo 4. Maliyet Tablosu.

\begin{tabular}{lll}
\hline FV Modül Monokristal & 320416 & $\$$ \\
\hline FV Modül Polikristal & 300018 & $\$$ \\
\hline İnverter & 106230 & $\$$ \\
\hline Arazi & 122000 & $\$$ \\
\hline Personel Binası & 8760 & $\$$ \\
\hline Personel Giderleri & 24300 & $\$ /$ yıllık \\
\hline Kablolamalar DC- AC & 65000 & $\$$ \\
\hline Konstrüksiyon & 85000 & $\$$ \\
\hline Koruma Ekipmanları & 25000 & $\$$ \\
\hline Trafo,beton köșk vs. & 38300 & $\$$ \\
\hline Bakım-Onarım-Temizleme & 9740 & $\$ /$ yıllık \\
\hline İșcilik+Nakliye & 66000 & $\$$ \\
\hline $\begin{array}{l}\text { Diğer ( Arazi düzenlemesi, } \\
\text { sigorta, projelendirme, } \\
\text { onay bedeli, kamera }\end{array}$ & 110000 & $\$$ \\
\hline
\end{tabular}

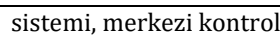

Tablo 5. Yapılan kabuller.

\begin{tabular}{ll}
\hline YEKDEM alış fiyatı $(10$ yıllık $)$ & $\begin{array}{l}0.133 \text { ABD doları/ } \\
\text { kWh }\end{array}$ \\
\hline Alım garantisi sonunda satış & $\% 40$ düşüş \\
fiyatı & öngörülmekte \\
\hline Elektrik satıș oranı & $\% 100$ \\
\hline Kredi süresi & 8 yıl \\
\hline Kredi faiz oranı & $\% 8.5 /$ yıllık \\
\hline Yıllık üretim azalması & $\% 0.7$ \\
\hline KDV & $\% 0$ \\
\hline
\end{tabular}

\section{Bulgular}

Çalışmada ilk olarak polikristal paneller kullanılarak 0,999 MW kurulu güce sahip sistemin tasarımı gerçekleștirilmiștir. Yıllık $1.573 \mathrm{kWh} / \mathrm{m} 2$ olan küresel ıșınımın \%14' ü kollektör üzerine gelmekte $\% 2,5$ ' i açı dönüşüm faktörü olarak kayıplara dönüşmektedir. Standart Test Koşullarında (STK) verim \%15,98 olmaktadır. Işınım seviyesine bağlı PV kaybı, sıcaklığa bağlı PV kaybı, modül kalite kaybı, kablolama kayıpları vs. dahil edildiğinde yıllık şebekeye verilen enerji $1.542 \mathrm{MWh}$ olmaktadır. Şekil 10' da polikristal paneller kullanılarak olușturulan santral için programdan elde edilen yıllık üretilen enerji kayıp diyagramı verilmektedir. 
DEÜ FMD 22(65), 517-526, 2020

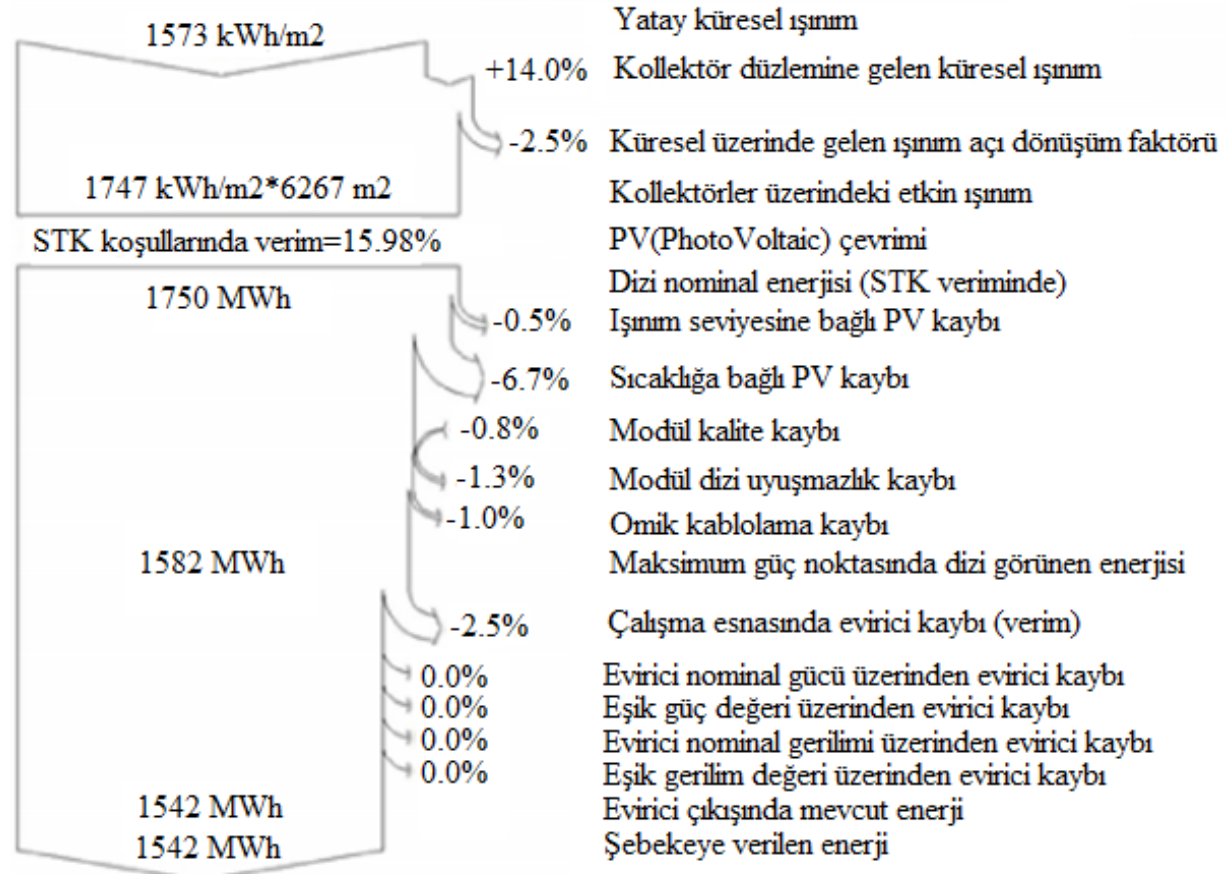

Şekil 10. Polikristal paneller kullanıldığında yıllık üretilen enerji kayıp diyagramı.

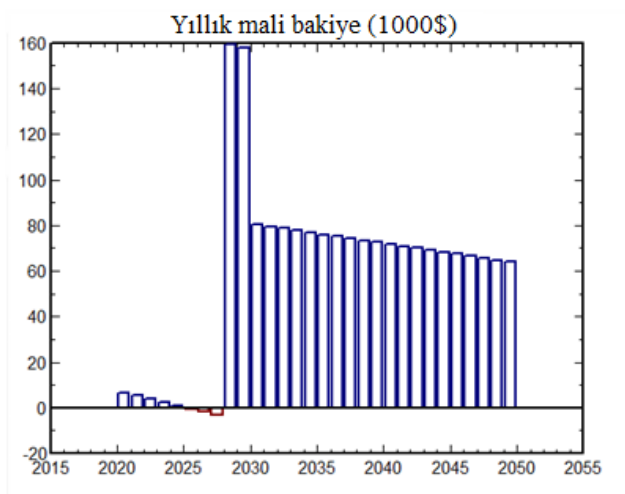

\begin{tabular}{|l|c|c|c|c|c|}
\hline Uzun vadeli ekonomik bakiye \\
\hline Y1 & $\begin{array}{c}\text { Borç } \\
8.5 \%\end{array}$ & $\begin{array}{l}\text { Isletme } \\
\text { giderleri }\end{array}$ & $\begin{array}{c}\text { Satllan } \\
\text { enerji }\end{array}$ & $\begin{array}{c}\text { Ylllkk } \\
\text { bakiye }\end{array}$ & $\begin{array}{l}\text { Kümülatif } \\
\text { bakiye }\end{array}$ \\
\hline 2020 & 164.3 & 34.0 & 205.1 & 6.8 & 6.8 \\
2021 & 164.3 & 34.0 & 203.6 & 5.3 & 12.1 \\
2022 & 164.3 & 34.0 & 202.2 & 3.9 & 16.0 \\
2023 & 164.3 & 34.0 & 200.8 & 2.5 & 18.5 \\
2024 & 164.3 & 34.0 & 199.3 & 1.0 & 19.5 \\
2025 & 164.3 & 34.0 & 197.9 & -0.4 & 19.1 \\
2026 & 164.3 & 34.0 & 196.5 & -1.8 & 17.2 \\
2027 & 164.3 & 34.0 & 195.0 & -3.3 & 14.0 \\
2028 & 0.0 & 34.0 & 193.6 & 159.5 & 173.5 \\
2029 & 0.0 & 34.0 & 192.2 & 158.1 & 331.6 \\
2030 & 0.0 & 34.0 & 114.4 & 80.4 & 412.0 \\
2031 & 0.0 & 34.0 & 113.6 & 79.5 & 491.5 \\
2032 & 0.0 & 34.0 & 112.7 & 78.7 & 570.2 \\
2033 & 0.0 & 34.0 & 111.8 & 77.8 & 648.0 \\
2034 & 0.0 & 34.0 & 111.0 & 76.9 & 724.9 \\
2035 & 0.0 & 34.0 & 110.1 & 76.1 & 801.0 \\
2036 & 0.0 & 34.0 & 109.3 & 75.2 & 876.3 \\
2037 & 0.0 & 34.0 & 108.4 & 74.4 & 950.6 \\
2038 & 0.0 & 34.0 & 107.5 & 73.5 & 1024.1 \\
2039 & 0.0 & 34.0 & 106.7 & 72.6 & 1096.8 \\
2040 & 0.0 & 34.0 & 105.8 & 71.8 & 1168.5 \\
2041 & 0.0 & 34.0 & 105.0 & 70.9 & 1239.4 \\
2042 & 0.0 & 34.0 & 104.1 & 70.1 & 1309.5 \\
2043 & 0.0 & 34.0 & 103.2 & 69.2 & 1378.7 \\
2044 & 0.0 & 34.0 & 102.4 & 68.3 & 1447.0 \\
2045 & 0.0 & 34.0 & 101.5 & 67.5 & 1514.5 \\
2046 & 0.0 & 34.0 & 100.6 & 66.6 & 1581.1 \\
2047 & 0.0 & 34.0 & 99.8 & 65.7 & 1646.9 \\
2048 & 0.0 & 34.0 & 98.9 & 64.9 & 1711.7 \\
2049 & 0.0 & 34.0 & 98.1 & 64.0 & 1775.8 \\
\hline
\end{tabular}

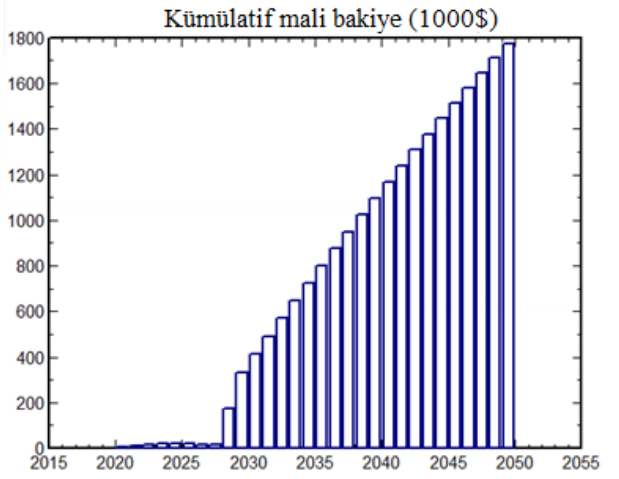

Şekil 11. Polikristal paneller kullanıldığında uzun süreli mali analiz 
DEÜ FMD 22(65), 517-526, 2020

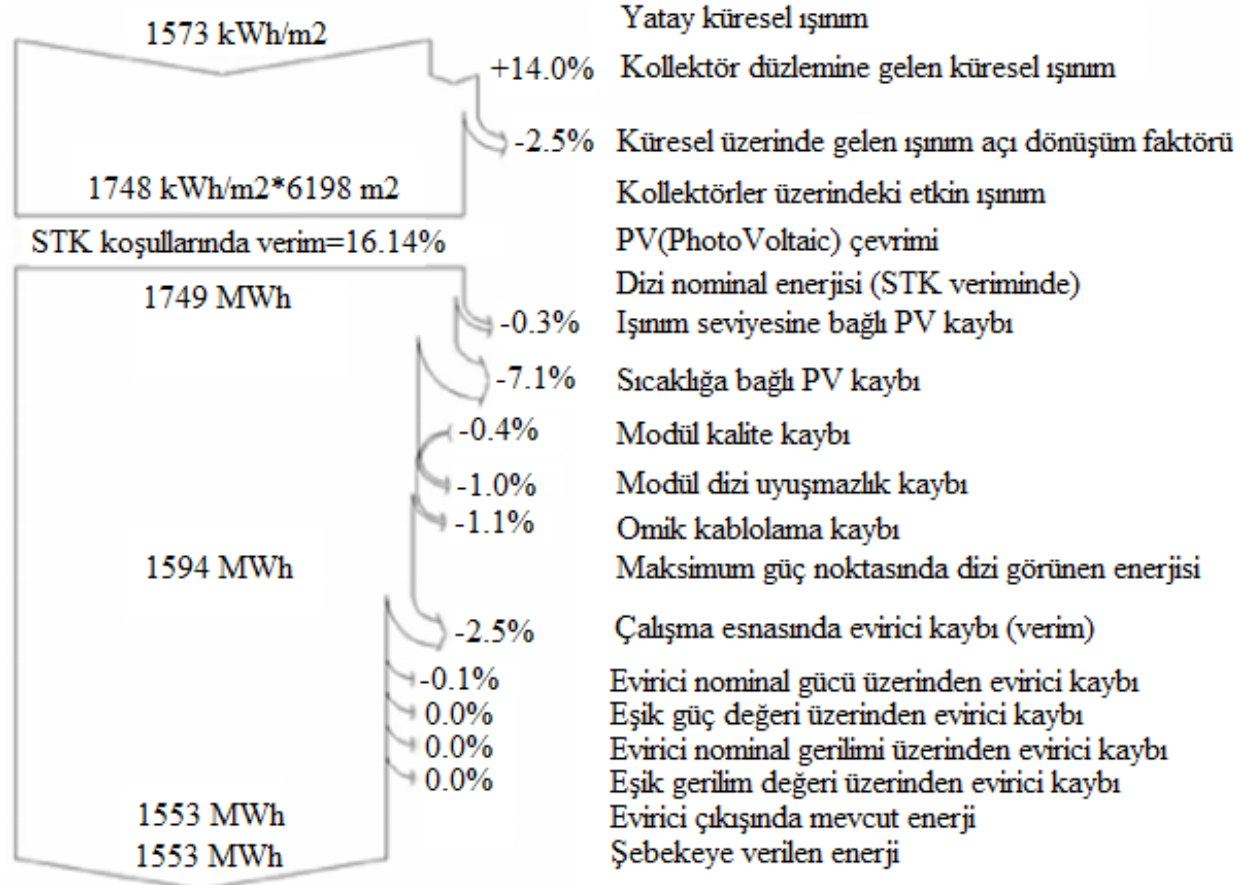

Şekil 12. Monokristal paneller kullanıldığında yıllık üretilen enerji kayıp diyagramı.
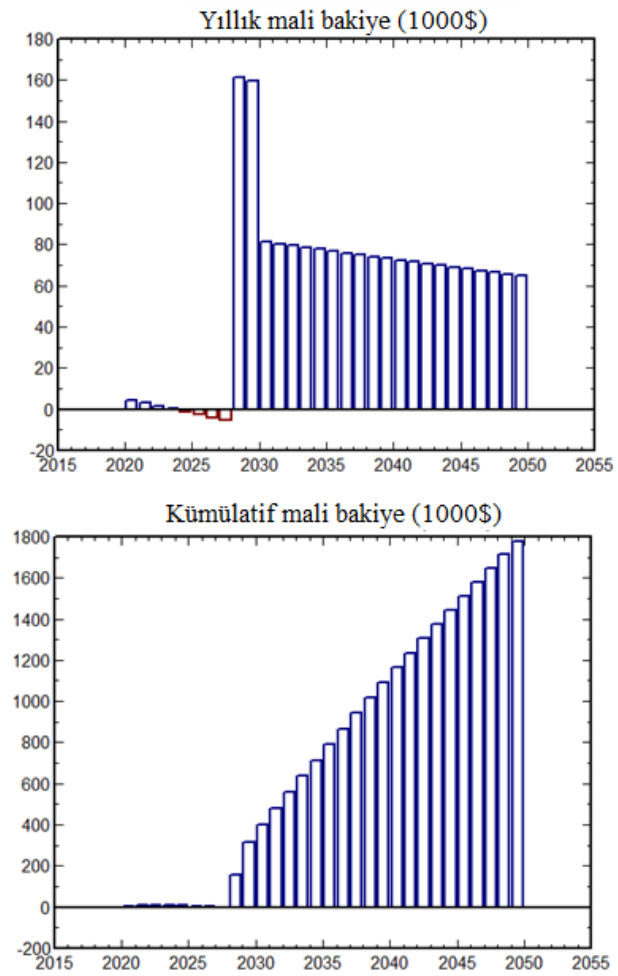

\begin{tabular}{|l|l|c|c|c|c|}
\multicolumn{7}{c|}{ Uzun vadeli ekonomik bakiye } \\
\hline Y1 & $\begin{array}{l}\text { Borç } \\
\text { ISșletme }\end{array}$ & $\begin{array}{c}\text { Satilan } \\
\text { giderleri }\end{array}$ & $\begin{array}{c}\text { Yillik } \\
\text { enerji }\end{array}$ & $\begin{array}{l}\text { Kümülatifi } \\
\text { bakiye }\end{array}$ \\
\hline 2020 & 167.9 & 34.0 & 206.6 & 4.6 & 4.6 \\
2021 & 167.9 & 34.0 & 205.1 & 3.2 & 7.8 \\
2022 & 167.9 & 34.0 & 203.7 & 1.7 & 9.6 \\
2023 & 167.9 & 34.0 & 202.2 & 0.3 & 9.9 \\
2024 & 167.9 & 34.0 & 200.8 & -1.1 & 8.7 \\
2025 & 167.9 & 34.0 & 199.3 & -2.6 & 6.2 \\
2026 & 167.9 & 34.0 & 197.9 & -4.0 & 2.1 \\
2027 & 167.9 & 34.0 & 196.4 & -5.5 & -3.4 \\
2028 & 0.0 & 34.0 & 195.0 & 161.0 & 157.6 \\
2029 & 0.0 & 34.0 & 193.5 & 159.5 & 317.1 \\
2030 & 0.0 & 34.0 & 115.3 & 81.2 & 398.3 \\
2031 & 0.0 & 34.0 & 114.4 & 80.4 & 478.7 \\
2032 & 0.0 & 34.0 & 113.5 & 79.5 & 558.2 \\
2033 & 0.0 & 34.0 & 112.7 & 78.6 & 636.8 \\
2034 & 0.0 & 34.0 & 111.8 & 77.8 & 714.5 \\
2035 & 0.0 & 34.0 & 110.9 & 76.9 & 791.4 \\
2036 & 0.0 & 34.0 & 110.1 & 76.0 & 867.4 \\
2037 & 0.0 & 34.0 & 109.2 & 75.1 & 942.6 \\
2038 & 0.0 & 34.0 & 108.3 & 74.3 & 1016.8 \\
2039 & 0.0 & 34.0 & 107.5 & 73.4 & 1090.3 \\
2040 & 0.0 & 34.0 & 106.6 & 72.5 & 1162.8 \\
2041 & 0.0 & 34.0 & 105.7 & 71.7 & 1234.5 \\
2042 & 0.0 & 34.0 & 104.8 & 70.8 & 1305.3 \\
2043 & 0.0 & 34.0 & 104.0 & 69.9 & 1375.2 \\
2044 & 0.0 & 34.0 & 103.1 & 69.1 & 1444.3 \\
2045 & 0.0 & 34.0 & 102.2 & 68.2 & 1512.5 \\
2046 & 0.0 & 34.0 & 101.4 & 67.3 & 1579.9 \\
2047 & 0.0 & 34.0 & 100.5 & 66.5 & 1646.3 \\
2048 & 0.0 & 34.0 & 99.6 & 65.6 & 1711.9 \\
2049 & 0.0 & 34.0 & 98.8 & 64.7 & 1776.7 \\
\hline
\end{tabular}

Şekil 13. Monokristal paneller kullanıldığında uzun süreli mali analiz. 
Sekil 11' de polikristal paneller kullanılarak oluşturulan sistem için programdan elde edilen uzun vadeli mali analiz gösterilmektedir. Güneş enerjisi santrali, bankadan sağlanan 8 yıllık kredi süresi içerisinde kredi ve işletme giderlerini ilk 5 yll boyunca ödeyebilmekte ve bu ilk 5 yıl kredi ve işletme giderlerini ödedikten sonra ek bir getiri sunmaktadır. Geri kalan 3 yıl boyunca ise panellerin verim kaybından dolayı üretilen enerji azalmakta ve enerji satışından sağlanan getiri düşmektedir. Sistem bu 3 yıl boyunca kredi ve ișletme giderlerini karșılayamamakta ve borçlanmaktadır. Sistemin 3 yıllık borçlanması toplamda $5.500 \$$ olmaktadır. 8 yıllık kredi süresi bittikten sonraki yıl sağlanan getiri ile bu borçlanma fazlasıyla karşılanmaktadır. Santralin ömrü boyunca enerji satışından 4.111.100\$ getiri sağlanmaktadır.

Diğer çalışmada ise monokristal paneller kullanılmış olup, 0,999 MW kurulu güce sahip sistem tasarımı gerçekleşmiştir. Yıllık 1.573 $\mathrm{kWh} / \mathrm{m} 2$ olan küresel ışınımın \%14' ü kollektör üzerine gelmekte ve $\% 2,5^{\prime}$ i açı dönüşüm faktörü olarak kaybolmaktadır. STK verimi \%16,14 olmaktadır. Dizi nominal enerjisi (STK veriminde) 1.749 MWh olmakta ve işınım seviyesine bağlı PV kaybı, sıcaklığa bağlı PV kaybı, modül kalite kaybı, kablolama kayıpları vs. dahil edildiğinde yllık $1.553 \mathrm{MWh}$ enerji şebekeye verilmektedir. Şekil 12' de monokristal paneller kullanılarak oluşturulan sistem için programdan elde edilen yıllık üretilen enerji kayıp diyagramı verilmektedir.

Şekil 13' de monokristal paneller kullanılarak oluşturulan güneş enerjisi santrali için uzun süreli mali analiz gösterilmektedir. Monokristal panellerden oluşan sistem 8 yıllık kredi ödeme süresi içerisinde, ilk 4 yll kredi ve ișletme giderlerini karşılamakta ve kredi ve işletme giderlerini karşıladıktan sonra ek bir getiri sunmaktadır. Geri kalan 4 yıl boyunca ise panellerin verim kaybından dolayı üretilen enerji azalmakta ve enerji satıșından sağlanan getiri düşmektedir. Sistem bu 4 yıl boyunca kredi ve ișletme giderlerini karșllayamamakta ve borçlanmaktadır. 4 yıllık borçlanma toplamda $13.200 \$$ olmaktadır. Kredi süresi bittikten sonraki yıl sağlanan getiri ile bu borçlanma fazlasıyla tolere edilmektedir. Santralin ömrü boyunca sağladığı getiri 4.140.900\$ olmaktadır.

\section{Tartışma ve Sonuç}

Yapılan çalışmada, 30 yıl boyunca gerçekleşecek enerji satışından elde edilen getiri monokristal paneller için 4.140.900\$, polikristal paneller için 4.111.100\$ olarak hesaplanmıştır. Her iki sistemden elde edilen getiri arasındaki fark 29.800 \$ dir. Monokristal panellerin toplam kurulum masrafı polikristal panellerden 20.398\$ daha fazladır. Buna karşın monokristal modül kullanılması durumunda monokristal modül veriminin daha yüksek olması sebebiyle sistem ömrü sonunda getirdiği kazancın $29.800 \$$ daha fazla olacağı tespit edilmiștir. Polikristal paneller kullanılarak olușturulan sistemlerde ise ilk kurulum maliyetlerinin monokristal panellere göre daha düșük olması sebebiyle daha erken dönüşler gözlemlenmektedir. Bu çalışmada elde edilen bulguların, Sivas Cumhuriyet Üniversitesi yerleșkesinde yapılması muhtemel olan güneș enerjisi santralinin kurulumunda faydalı olacağı düşünülmektedir.

\section{Kaynakça}

[1] United Nations. Population. https://www.un.org /en/sections/issues-depth/population/index.html (Erișim Tarihi: 29.11.2019).

[2] T.C. Enerji ve Tabii Kaynaklar Bakanlığı. Dünya ve Türkiye Enerji ve Tabii Kaynaklar Görünümü. https://www.enerji.gov.tr/Resources/Sites/1/Page s/Sayi_15/mobile/index.html (Erişim Tarihi: 29.11.2019).

[3] Türkiye Petrolleri Anonim Ortaklığı. Sektöre Dair. http://www.tpao.gov.tr/?mod=sektore-dair\& contID=42 (Erisim Tarihi: 29.11.2019).

[4] T.C. Enerji ve Tabii Kaynaklar Bakanlığı. Elektrik. https://www.enerji.gov.tr/tr-TR/Sayfalar/Elektrik (Erișim Tarihi: 29.11.2019).

[5] T.C. Enerji ve Tabii Kaynaklar Bakanlığı. Güneș. https://www.enerji.gov.tr/tr-TR/Sayfalar/Gunes (Erișim Tarihi: 29.11.2019).

[6] Yenilenebilir Enerji Genel Müdürlügü. Güneș Enerji Potansiyel Atlası. http://www.yegm. gov.tr/MyCalculator (Erișim Tarihi: 29.11.2019).

[7] Solargis. Solar resource maps of Turkey. https://solargis.com/maps-and-gisdata/download/ turkey (Erişim Tarihi: 29.11.2019).

[8] Taktak, F., Ilı, M. 2018. Güneş Enerji Santrali (GES) Geliștirme: Ușak Örneği, Geomatik, Cilt. 3(1), s. 1-21. DOI: 10.29128 /geomatik.329561

[9] Küçükgöze, O. M. 2016. Erzincan İlinde Güneș Enerjili Elektrik Üretim Sisteminin Ekonomik Analizi. Erzincan Üniversitesi, Fen Bilimleri Enstitüsü, Yüksek Lisans Tezi, 108s, Erzincan.

[10] Atakul, Ş., Kalender, M. A., Gezici, M., Eliçin, A. K. 2015. Güneș Tarlası Kurulumu, Tarım Makinaları Bilimsel Dergisi, Cilt. 11(1), s. 55-60.

[11] Aydın, E. H., Çunkaş, M. 2019. Artvin Çoruh Üniversitesi Seyitler Yerleşkesi Enerji Talebinin Yenilenebilir Enerji Kaynaklarıyla Karşılanması, Selcuk University Journal Of Engineering, Science 
DEÜ FMD 22(65), 517-526, 2020

and Technology, Cilt. 7(1), s. 241-252. DOI: 10.15317/Scitech.2019.195

[12] Çolak, Ş. Ç. 2010. Fotovoltaik Paneller Yardımı ile Günes Enerjisinden Elektrik Enerjisi Üretiminin Maliyet Analizi ve Gelecekteki Projeksiyonu. Yıldız Teknik Üniversitesi, Fen Bilimleri Enstitüsü, Yüksek Lisans Tezi, 121s, İstanbul.

[13] Orhun, M., Koca, Y. B., Hocaoğlu, F. O. Çınar, S. M. 2012. Farklı Yüzey Açılarındaki Işınım Şiddetlerinin Afyonkarahisar Bölgesi İçin Karşılaștırılması ve Güneş Panellerinden Elde Edilebilecek En Yüksek Elektrik Enerjisi Üretimi İçin Uygun Açlların Tespiti, Afyon Kocatepe University Journal of Science and Engineering, Cilt. 12, s. 1-5.

[14] Çağlar, A. 2018. Farklı Derece-Gün Bölgelerindeki Şehirler İçin Optimum Eğim Açısının Belirlenmesi, Süleyman Demirel Üniversitesi Fen Bilimleri Enstitüsü Dergisi, Cilt. 22(2), s. 849-854. DOI: 10.19113/sdufbed.94899

[15] Ceylan, O., Taşdelen, K. 2018. Isparta İli için Fotovoltaik Programlarının Simülasyon Sonuçlarının Doğruluğunun İncelenmesi, Afyon Kocatepe University Journal of Science and Engineering, Cilt 18, s. 895-903. DOI: $10.5578 /$ fmbd.67547

[16] Girgin, M. H. 2011. Bir Fotovoltaik Günes Enerjisi Santralinin Fizibilitesi, Karaman Bölgesinde 5 MW'lık Güneş Enerjisi Santrali için Enerji Üretim
Değerlendirmesi ve Ekonomik Analizi. İstanbul Teknik üniversitesi, Enerji Enstitüsü, Yüksek Lisans Tezi, 223s, İstanbul.

[17] Haydaroğlu, C. ve Gümüș, B. 2016. Dicle Üniversitesi Güneş Enerjisi Santralinin PVsyst ile Simülasyonu ve Performans Parametrelerinin Değerlendirilmesi, Dicle Üniversitesi Mühendislik Fakültesi Dergisi, Cilt. 7(3), s. 491-500.

[18] Yeşilbudak, M., Çolak, M. Bayındır, R., 2018. Ankara İlinin Uzun Dönem Global Güneș Ișınım Şiddeti, Güneşlenme Süresi ve Hava Sıcaklığı Verilerinin Analizi ve Eğri Uydurma Metotlarıyla Modellenmesi, Gazi University Journal of Science, Part C, Cilt. 6(1), s. 189-203. DOI: 10.29109/http-gujsc-gazi-edutr.336830

[19] Pvtech. Top 10 solar module suppliers in 2018. https://www.pv-tech.org/editors-blog/top-10solar-module-suppliers-in-2018 (Erişim Tarihi: 29.11.2019).

[20] Kaco. https://kaco-newenergy.com/company (Erişim Tarihi: 29.11.2019).

[21] Sayed, L., Hasanujjaman, M., Jaman, M. 2018. Performance Analysis of a Grid-Tied Solar PV System. East West University, Faculty of Sciences and Engineering, Department of Electrical and Electronic Engineering, B.Sc Thesis, 60p, Dhaka. 